\title{
Collective Representations, Divided Memory and Patterns of Paradox: Mining and Shipbuilding ${ }^{[1]}$
}

\author{
by lan Roberts \\ University of Durham \\ Sociological Research Online 12(6)6 \\ $<h t t p: / / w w w . s o c r e s o n l i n e . o r g . u k / 12 / 6 / 6 . h t m l>$ \\ doi:10.5153/sro. 1611
}

Received: 4 Oct 2006 Accepted: 7 Oct 2007 Published: 30 Nov 2007

\begin{abstract}
This paper seeks to examine the different relationship of two industries to their potential for representation and celebration in collective memory. Looking at case studies of mining and shipbuilding in the shared location of Wearside the paper compares and contrasts features of the two industries in relation to the divergent outcomes of the traces of their collective memory in this place. Using visual representations the paper makes the case that the mining industry has experienced a successful recovery of memory. This is contrasted to the paucity of visual representation in relation to shipbuilding.

The reasons for the contrast in the viability of collective memory are examined. Material, cultural and aesthetic issues are addressed. Contrasts are drawn between divisions of labour in the two industries and the ways in which these impact upon community and trade union organisation which further relate to the contrast between industrial and occupational identity. Differences in the legacy of the physical occupational communities of the two industries are illustrated. There is also an examination of the aesthetic forms of representation in which mining is seen as characterised by the aesthetics of labour, whereas shipbuilding is represented more through the aesthetics of product. The way in which the industries were closed also becomes important to understand the variation in the differences of the potential of collective memory. All of these strands are brought together to conclude that in relation to the potential for collective memory, mining can be seen to have gone through a process of 'mourning' whereas melancholia seems to more adequately represent the situation with respect to shipbuilding. In illustrating these cases the paper is arguing for a more sophisticated understanding of the process of deindustrialisation and the potential for the recovery of collective memory.
\end{abstract}

\section{Keywords: Collective Memory, Mourning, Melancholia, Deindustrialization, Post- Industrial Community, Locality, Mining, Shipbuilding}

\section{Introduction}

1.1 In their study of the closure of the Steel industry and deindustrialisation in Youngstown, Ohio, Sherry Linkon and John Russo (2002) argue that in order to understand the significance of deindustrialisation we must understand the part that is involved in struggle over memory. The representation of memory shapes not only the significance of the present for understanding the meaning of the past but also for shaping the legacy of the past in relation to potential for the future. Variations in such interpretations of the past are complex,

While some saw Youngstown as a place of loss and failure, others found hope in the community's determination and struggle. While earlier representations reflected conflicts over class and work, by the 1990s, the conflict focussed on how to remember the community's past. Would Youngstown be remembered as a site of loss or as a place of struggle, a symbol of failure or as an image of resilience? (Linkon and Russo, 2002, 132)

1.2 In assessing the past we do perhaps have to exercise some caution, for whilst our encounters with memories of the past underline the complex nature of recall and representation, sometimes we are less careful with the attribution of the structure and experience of the past as we project it 'there', not how it was 
remembered but how it was at the time. Thus for example we are told in one account of deindustrialisation that workers are expelled from a familiar world and enter 'a world of work organization largely alien to them.' In which, they find themselves navigating divergent sets of values - between the nominal solidarity and security of an industrial culture and the insecure, individualized world of service and high-tech work.' (Cowie and Heathcott (eds) 2003, 13) The problem with such a formulation is that it perhaps over homogenises the legacy of work in the past for manual workers and, by implication, finds greater fragmentation in the present. Now on one level I agree with such a conclusion, that the 'stability' of the aggregate demand for labour during the period of the Fordist welfare state did provide not only an unprecedented period of stability for manual workers, but also with tight labour markets, a framework in which the strategic demands and instrumental collectivism of workers achieved much. However, whether this can be characterised as the 'solidarity and security of an industrial culture' is perhaps more problematic. To predicate a solidaristic collectivism based on industrial culture is perhaps to oversimplify the past and by implication over fragment the present.

1.3 In this paper I am seeking to explore the complexity of the past and the present with respect the process of deindustrialisation and the divisions of memories of former work and community as a way to produce more adequate understandings of the processes involved. Importantly this paper does not focus upon just one industry but attempts to look at elements of both mining and shipbuilding within one locality. I am stressing the importance of place because it is likely to be as important as industrial subculture. Thus the local character of shipbuilding, for example, is somewhat different on Wearside to that which grew up on Clydeside, which at historical points produced not only the first shop stewards movement (Hinton, 1973) but also had a local constituency that returned a communist MP (Gallacher, 1978). So in focussing upon Sunderland and its local area I am seeking to contain variation in terms of place. Thus the focus on two forms of work within the locality has the benefits of being able to produce complex case studies through which both differences and similarities can be appreciated. Again I wish to stress that this account is an attempt to produce an 'historical individual' in Weber's sense. In looking at how the legacies of two industries in the same locale have been represented and contested the account draws on general features related to those industries, eg, the availability or otherwise of iconic images to stand for the industries and their activities. But also to look at the unique circumstances that predispose communities either to seek to preserve memories or to abandon them. Thus it is not my argument that the legacy of mining is always a radical one and that shipbuilding produces a more reactionary response. One need only look at Nottinghamshire in relation to mining or Clydeside in relation to shipbuilding to see opposite scenarios which show that I am not pursuing an essentialist argument here. Rather I wish to try to understand why the legacy of the mining industry on Wearside seems to be so resurgent whilst that of the shipbuilding industry has largely foundered. In this paper then;

We seek knowledge of an historical phenomenon, meaning by historical: significant in its individuality. (Weber 1949, 78)

\section{Representation}

2.1 The inspiration for this paper and its main starting point is the notion that representations of the two industries have had rather different histories since the closure of the mines and the shipyards. Forms of representation of the legacy of work in the mines seem to be popular and still growing. Not only is the annual Durham miners gala still functioning but as Carol Stephenson and Dave Wray (2005) have noted, some ex-mining villages have been recently or are currently involved in commissioning new mining banners. Moreover the representation of mining has received funding from both public and private sources and importantly has been adopted by those with no history within the industry itself. Where mining villages themselves seek to represent memory of the industry in artwork, it is the symbols and representations of the work and the workers themselves that predominates. Some examples of this can be seen in the following photographs. 


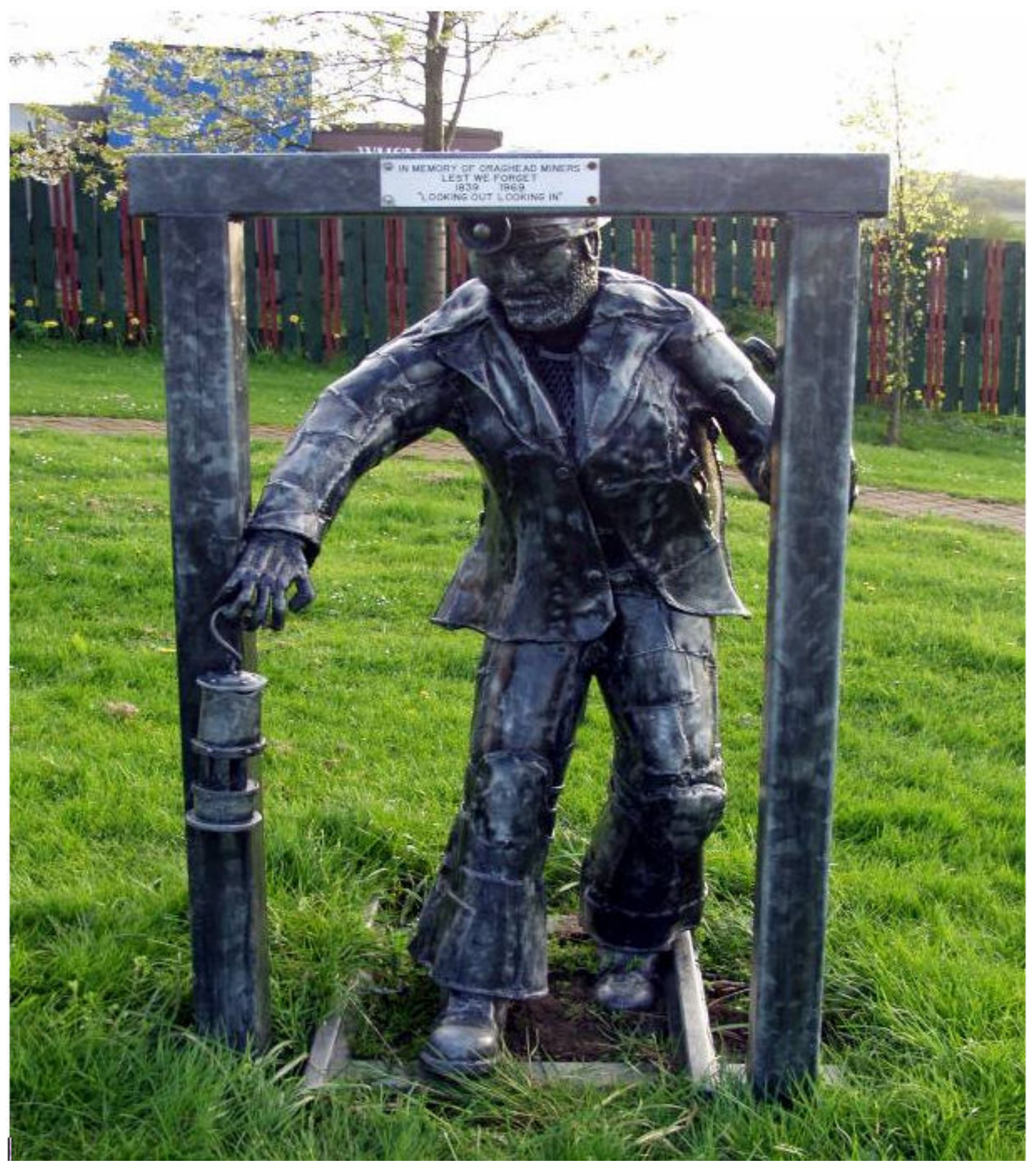

2.2 This first photograph is of a life sized miner in steel, note the miners lamp held in the right hand. As we shall see below, the lamp has become an emblematic of the mining industry. 


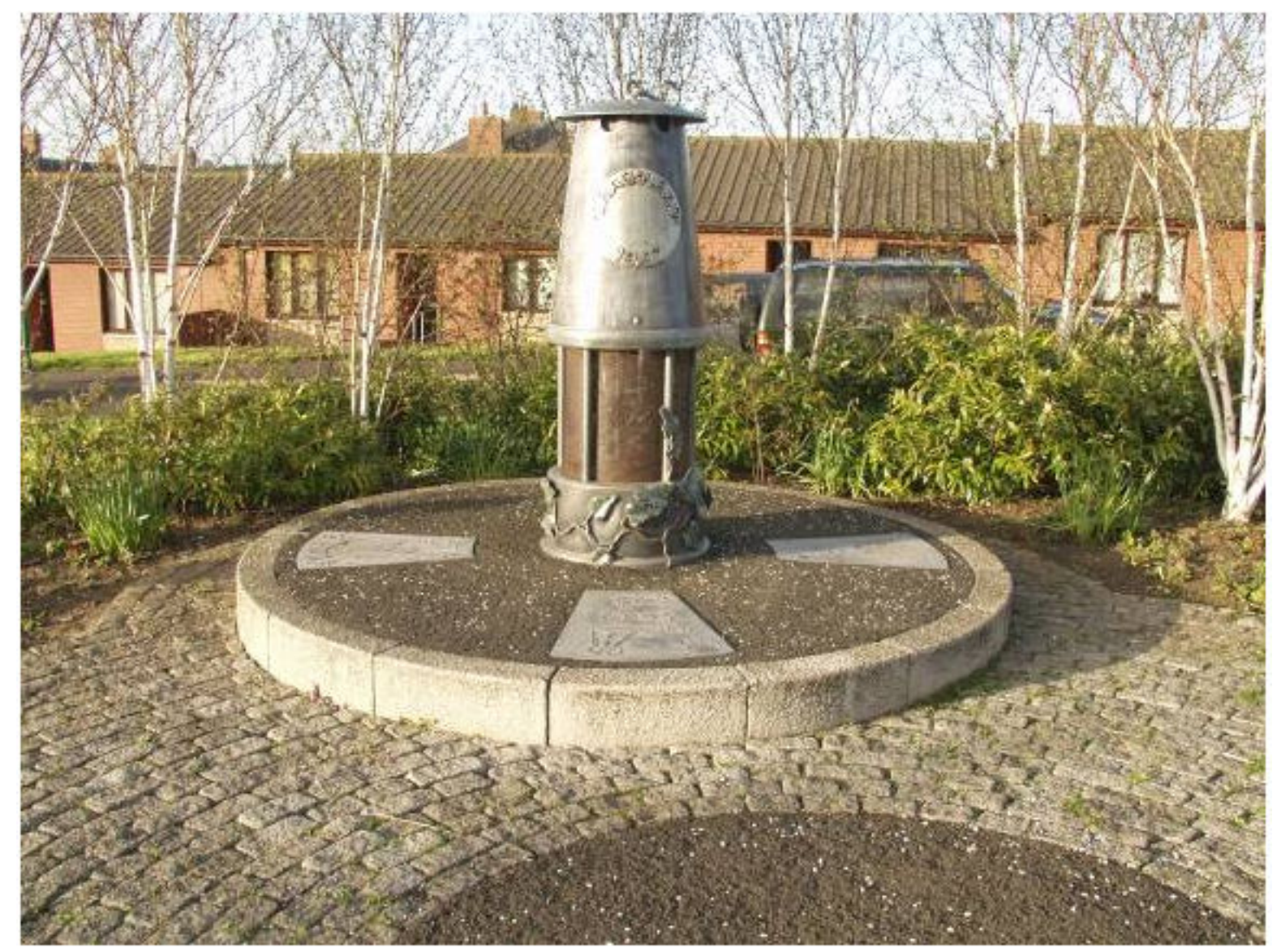

2.3 This lamp is located in the same village. The ivy that can be seen climbing up from the bottom of the lamp perhaps speaks of the passing of the industry together with the 'greening' of post-industrial spaces. There is also an interesting juxtaposition of generational representation going on here. The small cottages visible in the rear of the photograph are 'aged miners cottages' housing provided by the union for retired and infirm ex-miners. The steel plates around the bottom of the lamp incorporate artwork that was developed in the local primary school in workshops run by the artist. The artwork then incorporates the various generations of the village and attempts to encourage the children with no direct experience of mining to take ownership of the legacy of the mining tradition. The money for the pieces of sculpture was raised by a local action group and several sources of public funding both local and national were accessed. This clearly shows that in such communities there is a determination to claim the ownership of collective representations. The action group commissioned the artist to produce both pieces of sculpture and worked in an ongoing relationship with the sculptor as did the local school and other community groups.

2.4 The next photograph shows a similar but much bigger piece. What is perhaps significant here is that this work was not commissioned by a community but by a private firm, in this case Sunderland football club. They built their new stadium on the site that had been the location of Wearmouth pit in Sunderland. This location together with the fact that they chose to call the new ground the 'Stadium of Light' encouraged the sculptor to approach them with the idea that they needed a light in the shape of a miners lamp to represent the history and legacy of the place. 


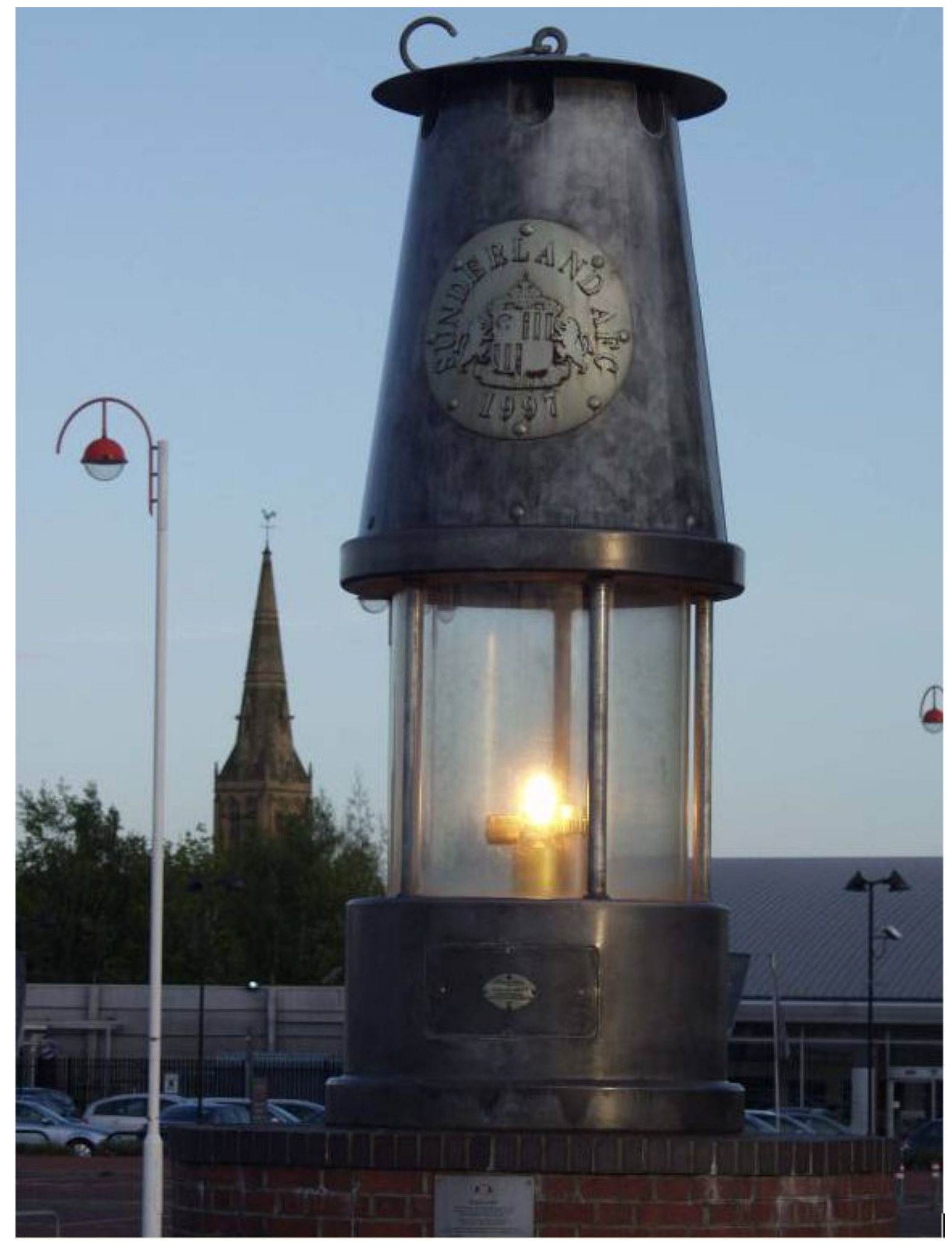

2.5 The lamp is some three meters high and stands on a plinth that is another meter in height. The badge on the front of the lamp is that of Sunderland Association Football Club which again emphasizes that they are claiming ownership of the symbol and the memory of mining that it represents.

2.6 The significance of such artwork is that the symbolism that it represents is embraced by those beyond the individual communities themselves. Certainly with the stadium light the representation of mining is transposed from the industrial to the post industrial setting. In Sunderland, a town described by one academic as a 'clapped-out industrial dump' (Byrne, 2001, p59) the legacy of mining is preserved by association with one of the few 'successful' businesses left, the football club. For the memory of the industry and particularly the former workers, the ability of the symbols to appeal beyond the direct community itself is a very significant point in preserving the potential of memory. The notion of the lamp is a particularly appealing symbol in this respect. For, as others have argued, (see below) symbols with religious appeal exercise a particularly strong effect. In this sense the lamp symbolises the notion of the light in the darkness shining out as a beacon for all.

2.7 There is another significance to the sculptures portrayed above. They are all the work of one artist. The 
significance of this lies in the background of that artist. For fifteen years he was employed as a plumber/welder within the shipbuilding industry in Sunderland. The irony lies then in the fact that as an artist this ex-shipbuilding worker is spending a lot of his time producing artwork that celebrates the memory of the mining industry but has not received any commissions to produce work related to shipbuilding. $\mathrm{He}$ did, however, have a bid to do such work turned down by the local council. Here we arrive at our central paradox then, why should the representation of mining have such an appeal in Sunderland and the local region when the preservation of the memory of shipbuilding seems to be facing an uphill struggle. There is a group seeking to promote the history of shipbuilding in the town as well as a campaign for a maritime museum. However support for such initiatives both from past workers as well as official agencies seems to be at best lukewarm, while some are actively hostile. How can we explain this? If it was the case that mining was a far more important industry in Sunderland than shipbuilding then we might understand the appeal of one and lack of interest in the other. However, since the early years of the nineteenth century the shipbuilding industry in Sunderland had been the dominant industry within the town. Indeed as early as 1835 Lloyd's Register recognized the importance of Sunderland for the national industry seeing it as;

...the most important shipbuilding centre in the country, nearly equalling as regards number and tonnage of ships built in all the other ports together. (quoted in Dougan, 1968, 27)

2.8 Even into the post Second World War years it was proclaimed as the biggest shipbuilding town in the world' (Smith and Holden, 1947) In the early post-war years numbers employed in the yards in Sunderland exceeded 10,000 workers and even by the the late 1960's it was still identified as the dominant industry within the town (Robson, 1971).

2.9 The relative lack of interest in the memory of shipbuilding compared to mining cannot then be explained by the overall importance of the two activities within the town. To understand the relative claims for memory we have to begin to unpack a complex story which ranges from the aesthetics of labour, the material processes involved in the labour process, the division of labour and trade unionism, through issues of housing and physical occupational communities and finally to the nature of the closure of the industries. Some of the issues are general ones independent of place others are locally specific. In the rest of the paper I shall try to weave the different levels of the account together in order to represent the full complexity of the process and experience of deindustrialization and the shaping of collective memory.

\section{The aesthetics of labour and the aesthetics of commodity.}

3.1 We saw in our earlier images that there are forms of representation of mining such as the lamp that are related to the centrality of labour. It is not so simple to find any such iconic image for workers in the shipbuilding industry. For as we shall see their crafts are often very different as are their tools. However there is an even more fundamental problem with respect to representations of the two industries. It is part of my argument that whereas representations of mining centre upon an aesthetics of labour this is absent with respect to shipbuilding. Consider the following, when one undertakes a 'google' image search using the words 'coal miner' a large number of images are forthcoming.

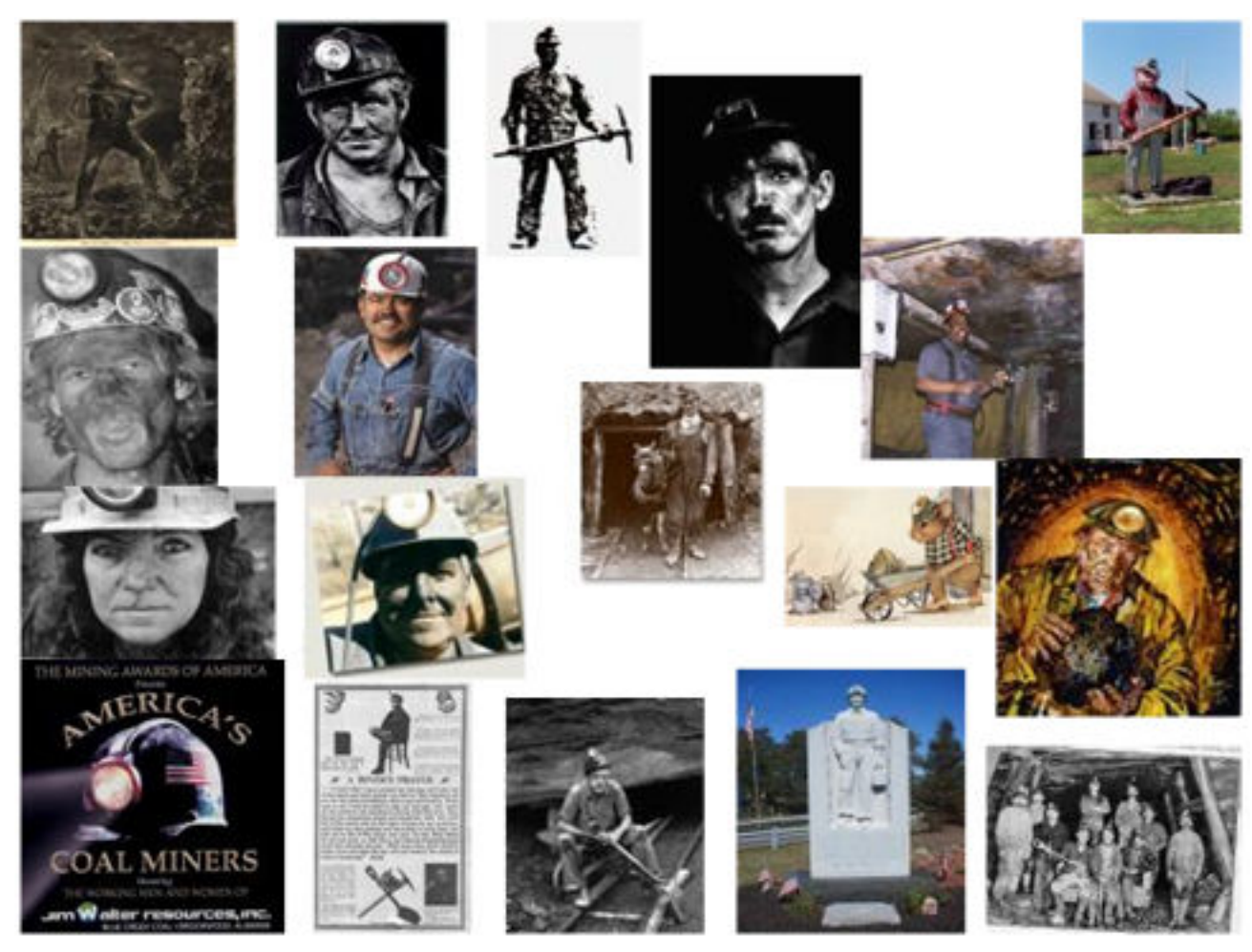

3.2 As you can see the dominant image is that of a miner, even if in one case it is a cartoon mining mouse! The centrality of mining labour is clearly emphasized. However when we repeat the exercise and insert the search term 'shipbuilder' we get a very different profile. 

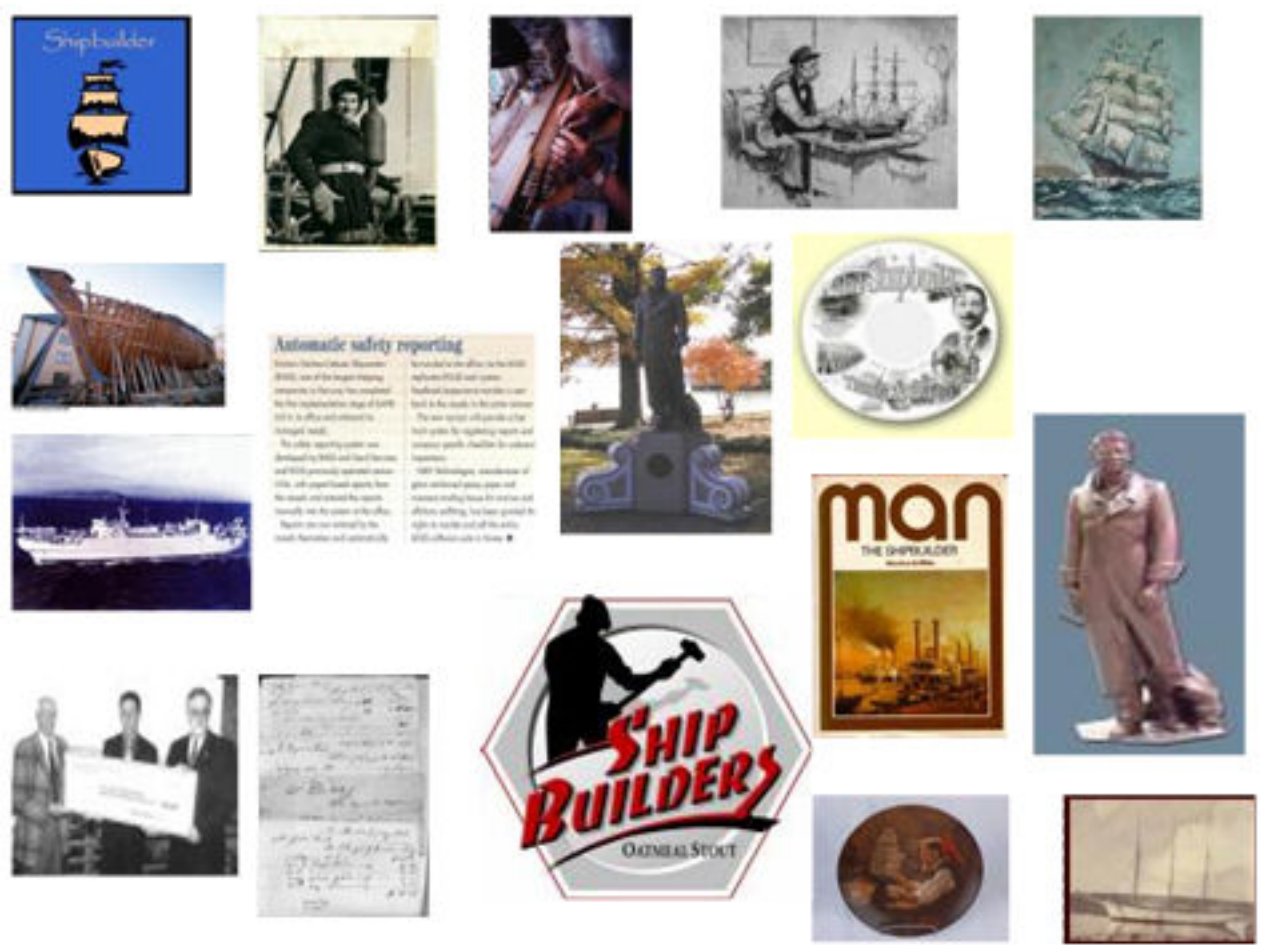

3.3 As you can see in the above images there are five representations of ships on their own, there are three images of model ships being built. There is only one photo of what might be a person in a shipyard and she is a woman. There is one statuette that might be a shipbuilding worker and the only image of a worker apparently wielding a tool is an advert for beer! Now it may be objected that coal miner is an occupational classification in a way that shipbuilder is not so I repeated the exercise using the term 'shipyard worker' which I would argue puts labour at the centre. The following results are obtained
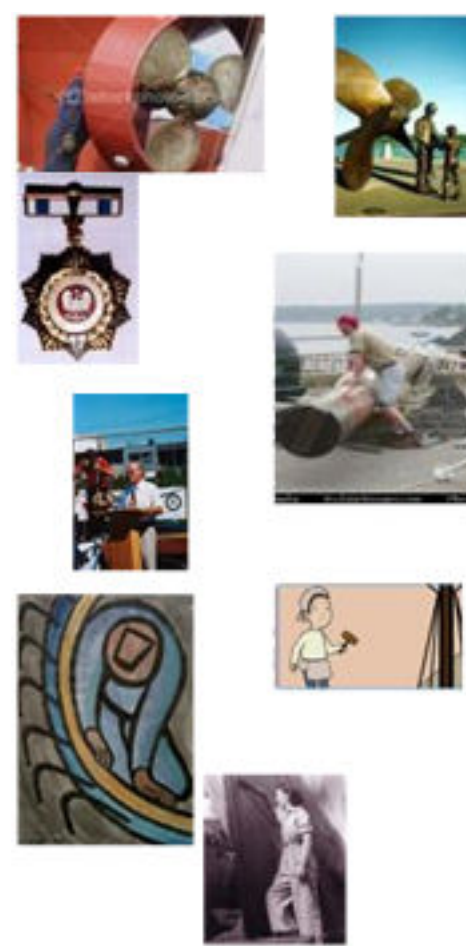
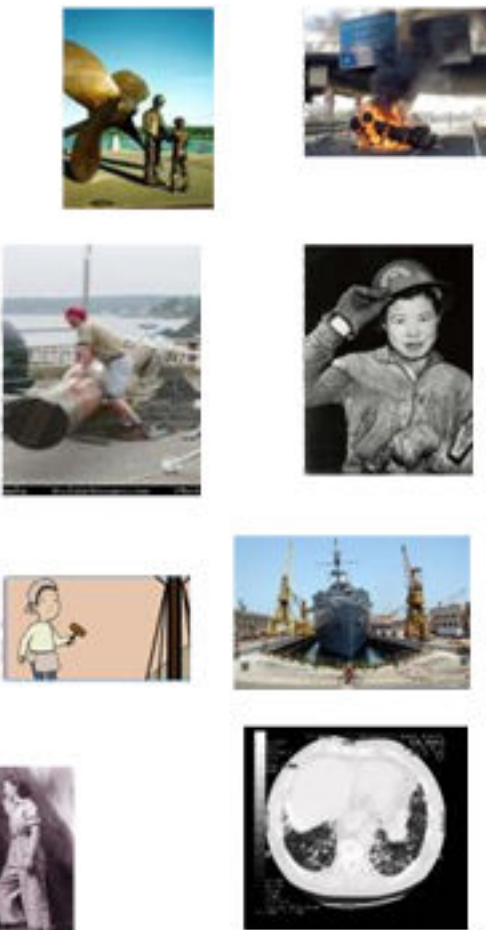
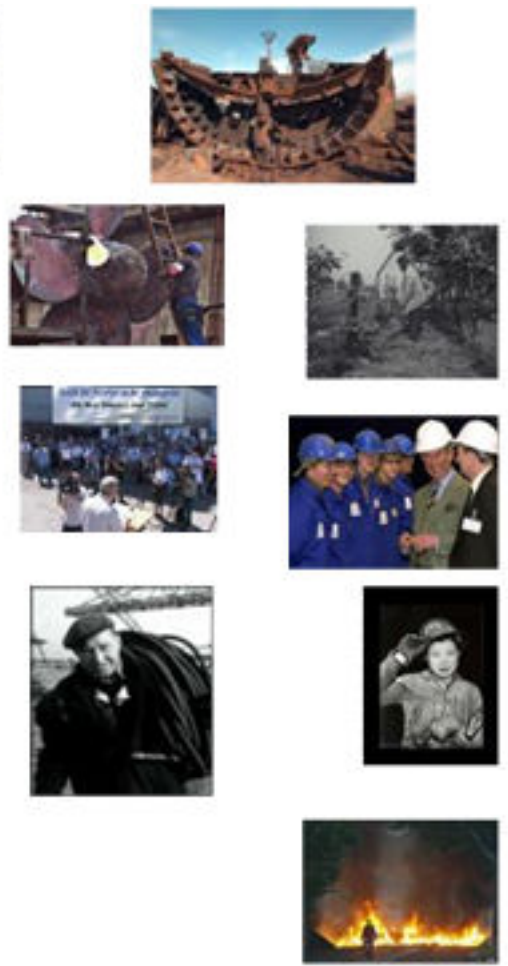

(These images were all accessed on 15 May 2005)

3.4 What I would ask you to notice is the heterogeneity of the images generated here in contrast with the homogeneity of images when the term coal miner is deployed. In the case of 'shipyard worker' three images of women workers are produced. In the UK this is a phenomenon unique to wartime. There is also a picture of a dry dock with a ship in it. Other images show workers dwarfed by the propellers that they are working on. There is no single type of image that dominates, moreover where the images are clearly and directly related to shipbuilding it tends to be the ship itself or the scale of the yard that attracts our attention. This then is another dilemma in trying to envisage what commemoration of shipbuilding workers would look like. For mining the centrality of labour and the lamp focuses our attention on a limited number of iconic representations. In shipbuilding there is a tendency for the aesthetics of the commodity, of the 
ships themselves to dominate. It is as if a form of artistic alienation were evident in relation to the representation of workers in the shipbuilding industry. In relation to two of Marx's four types of alienation, alienation of the product and alienation in the process of production there almost seems to be an inversion between the two industries. Mining as an 'unskilled' industry has been seen to involve alienation in the process of production, whereas the product, through its very mundane nature, is used by the community itself. In shipbuilding with a craft division of labour, alienation is seen to exist less in relation to the process of production but clearly the ship itself sails away at the end of the production process, workers are therefore alienated from the product of production. The finished product dominates over the process of production in terms of aesthetic impact.

3.5 These are all important considerations for understanding the ways in which images as general resources can be drawn on and accepted, or rejected, both by the communities themselves and those beyond. The history of photography demonstrates a suspicion not only of what has been called 'documentary photography' but also even within that tradition anything that demonstrates a concern with humanism as applied to the masses. There are then two features to this argument. Firstly in representing work there has been a far stronger acceptance of the 'machine aesthetic'. In the United States in particular the appeal of the machine aesthetic was demonstrated photographically in the work of Charles Sheeler, Margaret Bourke-White and Ben Glaha. They drew inspiration from European sources in the work of Germaine Krull and the influence of the Bauhaus. Even Paul Strand was caught up in this enthusiasm declaring that,

...through the scientist/inventor a new technological Trinity had emerged: "God the Machine, Materialistic Empiricism the Son and Science the Holy Ghost." Strand's comment, in declaring that God was not humanistic but mechanistic, was the transcendent abdication of authority from man to machine. (Vilander 1999, 54)

3.6 There were of course other reasons why photographic artists might want to minimize the visibility of workers within the workplace. Karen Lucic made the following general observations when discussing Charles Sheeler's photographic work for Henry Ford,

Workers rarely appear in the Rouge photographs...This kind of presentation was by no means new. Since the nineteenth century, photographs of factories had consistently presented workers as mere ciphers or appendages to machines. To feature workers might reveal too much about the unpleasant aspects of factory labour and, in any event, the buildings and equipment were often the most significant aspects of the industrial enterprise from the management's perspective. (Lucic 1991, 92)

3.7 Those who neglected both the way the aesthetic wind was blowing and the pragmatics of who paid for work photographs were likely to die in poverty as indeed the foremost proponent of work photographs as an enduring human document, Lewis Hine, did!

3.8 My point then is that what I have called the aesthetics of product in relation to shipbuilding and the relative neglect of labour is characteristic of a wider tendency of the machine aesthetic. In this comparison it is the dominance and popularity of the aesthetics of labour in the mining industry that seems to require further explanation. The mundane nature of the product of that industry has already been mentioned. However there is another feature of mining that renders a machine aesthetic problematic and that has been referred to by Byrne and Doyle,

No photograph can give a sense of the vastness of underground undertakings. (Byrne and Doyle 2004, 168)

3.9 As far as a machine aesthetic is concerned the coal mining industry has not represented fertile territory. Yet the aesthetics of labour represented in the google images of miners above are of a particular kind. The black-faced miner with helmet and lamp preserves a kind of anonymity of 'type'. Examples of miners that reveal more about them as individual human beings are a rarer genre and form something of a niche market (eg, Chrismas 1998). The iconic image of the anonymised blackfaced miner is their importance of a type upon which a variety of audiences can inscribe their own meanings. This is part of the reason why the icons of mining appeal beyond their immediate community. Again this emphasis upon type when representing working people is an established practice. In the work of Bill Brandt some of his most famous photos of working class London actually used images posed by his immediate relatives, ironically representatives of the European high bourgeoisie, as one commentator observed,

Bill Brandt's pictures of London people are not portraits; they are generalizations. He is not so much concerned about individuals as about types...This means not so much catching people unaware as getting the right people against the right background - the right types in the right places. It does mean catching the spirit of London life. As opposed to the idea of candid portraiture, it does not matter for his purposes that the people he is photographing may be aware of his presence or may even be holding it for him. Nor does this sort of posing, if it can be called that, affect the truth of his pictures. (Norah Wilson quoted in Delany 2004, 129)

3.10 The importance of type then can be seen to be represented in the iconic appeal of the blackfaced miner, its very homogeneity renders it as a vessel of almost infinite malleability of meaning. 'It' can be claimed as a repository of meaning by a variety of audiences, including those of the communities of origin themselves. It is a non-humanist, human type, as an heroic icon it invites mythic investment not uncomfortable or inconvenient actual comparison. Like the 'British Tommy' the blackfaced miner is a repository of resolution, tenacity and reassurance rather than the sum of their actual activities. Therein lies 


\section{The Basis for Solidarity: Past Structures and Processes.}

4.1 It is my argument that part of the potential for general and overarching iconic forms of the representation of labour in particular industries is related to the level of solidarity that existed within specific workforces. This relates not only to the potential to conceive of such images but also the willingness of particular communities to claim such images once generated. Inevitably there is a complex of factors that go together to produce the potential for solidarity in any particular industry. The factors that can be enumerated produce merely a potential. Whether that potential is realized at particular points in time owes as much to agency as to structure, as people to paraphrase Marx, struggle to make history but not in circumstances of their own choosing. In this section of the paper I shall outline some of the salient differences between the two industries.

4.2 For those seeking to understand the nature of mining communities and particularly with respect to issues of solidarity and willingness to struggle against employers much is made of both the issue of place and location and the nature of the labour process. The importance of place in the mining industry has been pointed to by Kerr and Siegal (1954) as an explanation for levels of solidarity and strike proneness of the industry, they argue that the more isolated communities were, the more strike prone they tended to be. However Andrew Richards has pointed to a rather more complex interaction between place and the nature of work,

The brutality of their work, the isolation of mining settlements and their consequent emergence as occupational communities did much to reinforce such perceptions on the part of both miners and non-miners alike. Furthermore several studies argue that such characteristics made mining communities more militant than other segments of the working population. (A.J. Richards, 1996: p.16 )

4.3 Similarly, Church and Outram (1998) have argued for an approach that links issues of the nature of work to the location of such communities, but also that we need to situate these things within the necessarily conflict ridden social relations of capitalism. Place is of importance but isolation can be social as well as geographical and, in relation to distinct communities, can both be claimed from within as well as enforced from without. In the Durham coalfield the importance of geographical isolation is to the fore in relation to pits in the inland places in the west of the county. This of course contrasts most starkly with the situation of the shipbuilding industry based on rivers which have tended to be long established ports and therefore in communities characterized by openness to the wider world and through which the globalised relations that stem back at least as far as the beginning of the British Empire can be traced. However, importantly in the case of Sunderland, the mines of Wearmouth colliery and Castletown were themselves only a 'stone's throw' from the river. The former occupied what could be argued was an inner city site while the latter was submerged within the growing boundaries of the town, a situation reinforced by the growth of council housing estates in the period just before, and more especially immediately after, the Second World War. I would want to argue that even within the bounds of the same place the extent to which the two occupational communities were afforded the opportunity to enforce collective boundaries around their communities differed, as did the willingness to exercise such opportunities that did exist. In part this related to the kinds of housing that miners and shipbuilding workers occupied. As Beynon and Austrin have argued the mining industry in Durham was characterized by paternalism,

Everywhere, though, the practices of the new employers bore the stamp of paternalism; a stamp that characterised labour relations and social relations generally in the Durham coalfield for a century and more. ( H. Beynon and T. Austrin, 1994, p23)

4.4 One element of that paternalism was the provision of colliery housing. Paternalism of course should not be confused with altruism. The provision of housing helped ensure a labour supply and could be used very directly as a weapon against the workers, as in the strike of 1844, where, 'In the Londonderry collieries the miners and their families were evicted from their houses.' (Beynon and Austrin, op cit, p34). Nevertheless the employers had a direct interest in providing housing that ensured labour supply, they built physical occupational communities. In Durham the mining industry was built on the basis of the provision of company housing as in the nineteenth century 'almost 90 percent of miners lived in company houses, which were provided as part of the wage' (Beynon and Austrin, opcit, p22).

4.5 In relation to the shipbuilding industry it has been argued (Roberts, 1993) that the employers in Sunderland were less interested in direct paternalism as specific employers and were more interested in what has been described as the 'politics of local loyalties'. There is good reason for this, because of the long product cycle of shipbuilding and the varying requirements for different types of labour at different stages of the process workers tended historically to be quite mobile between different yards, especially in periods of slack labour markets. Hence direct paternalism with its emphasis upon stabilizing workforces, was not an appropriate strategy, when what was called for was labour that was mobile between the different enterprises. In terms of housing this meant that, whilst in relation to mining, employers had a direct interest in building houses that were, at least to a minimum degree, fit for purpose and subsidised, for shipbuilding workers housing was constrained by what the market could provide and what the workers could afford. In Sunderland this resulted in two contrasting types of housing for miners and shipbuilding workers.

4.6 For miners, housing provision tended to vary, not only in relation to level of occupation, larger housing for mining engineers and managers, but also for miners themselves larger and smaller houses were a feature. Thus in the photographs below we see former colliery housing in Castletown in Sunderland. 


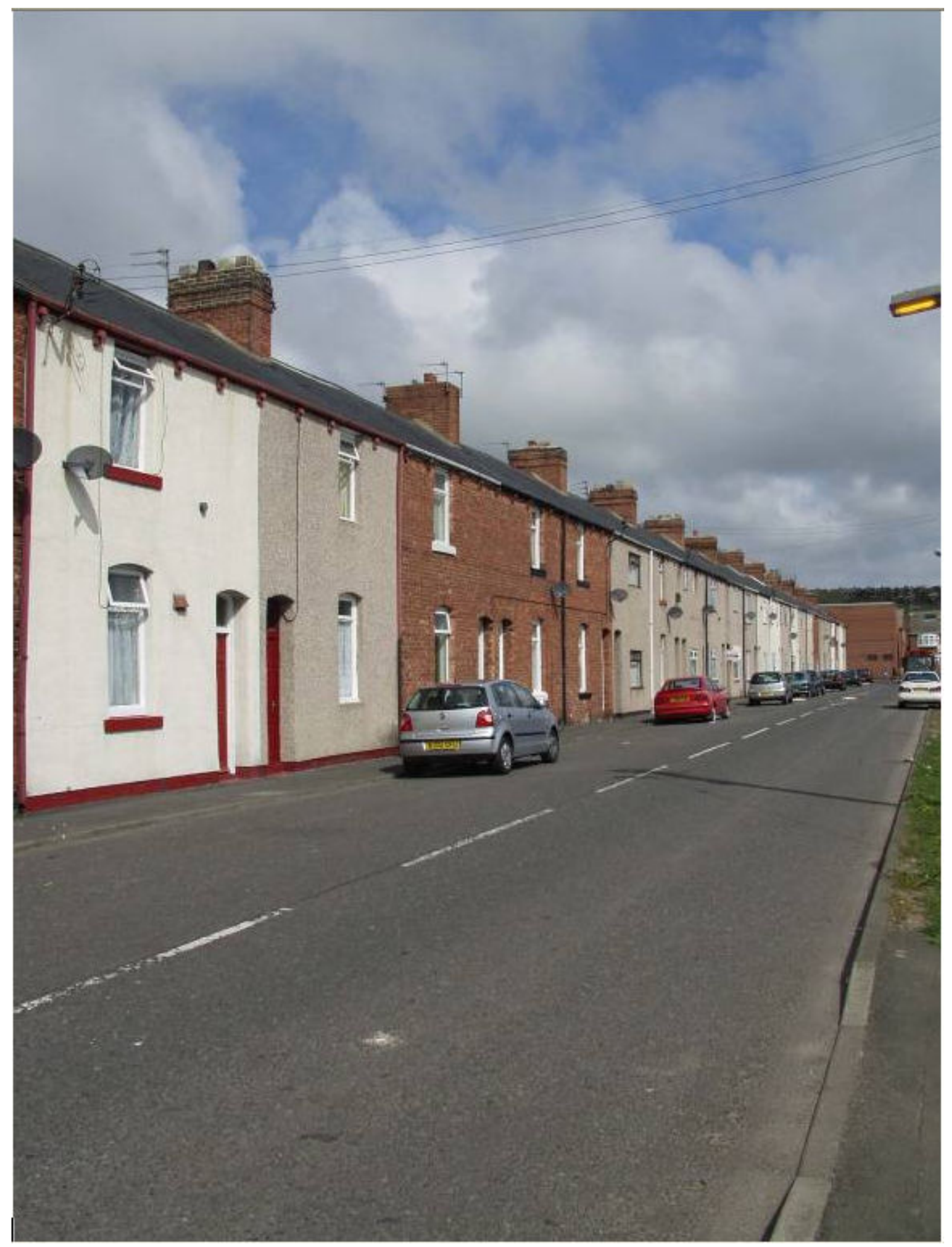




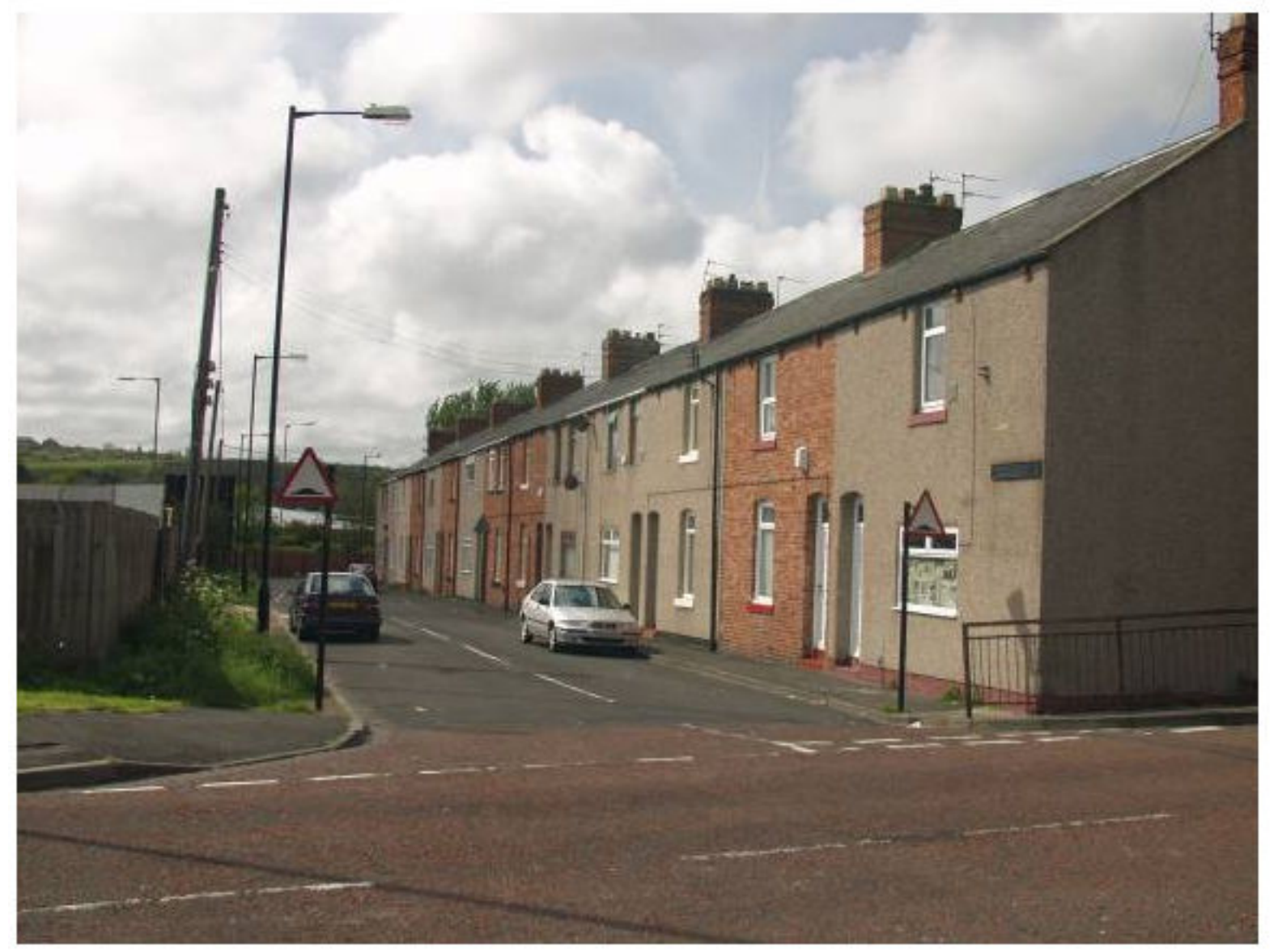

4.7 These houses are two storey terraced houses that make good sized family homes, many with two or three bedrooms. The pit entrance used to be at the far end of this terrace.

4.8 The comparison with the housing that shipbuilding employees tended to live in is quite stark. Sunderland boasts a form of housing that is unique in England, known as 'artisan cottages'. From as early as the nineteenth century some shipbuilding workers accrued enough money to buy their own houses, frequently also providing rented accommodation for a non-family member as well. Having to face a private housing market meant that the scale of houses that could be bought was somewhat less than at least some of the colliery houses that were available. Even then it was the best paid workers that could afford there own cottages as Carol Roberton has argued,

... with many of the workers moving into the new single storey cottage streets which were a unique development in an English town. Typically it was the shipyard craftsmen with their relatively high wages who were able to buy their own cottages. (Roberton 2004, 19-20)

4.9 As we can see below, artisan cottages tend to be rather small. 


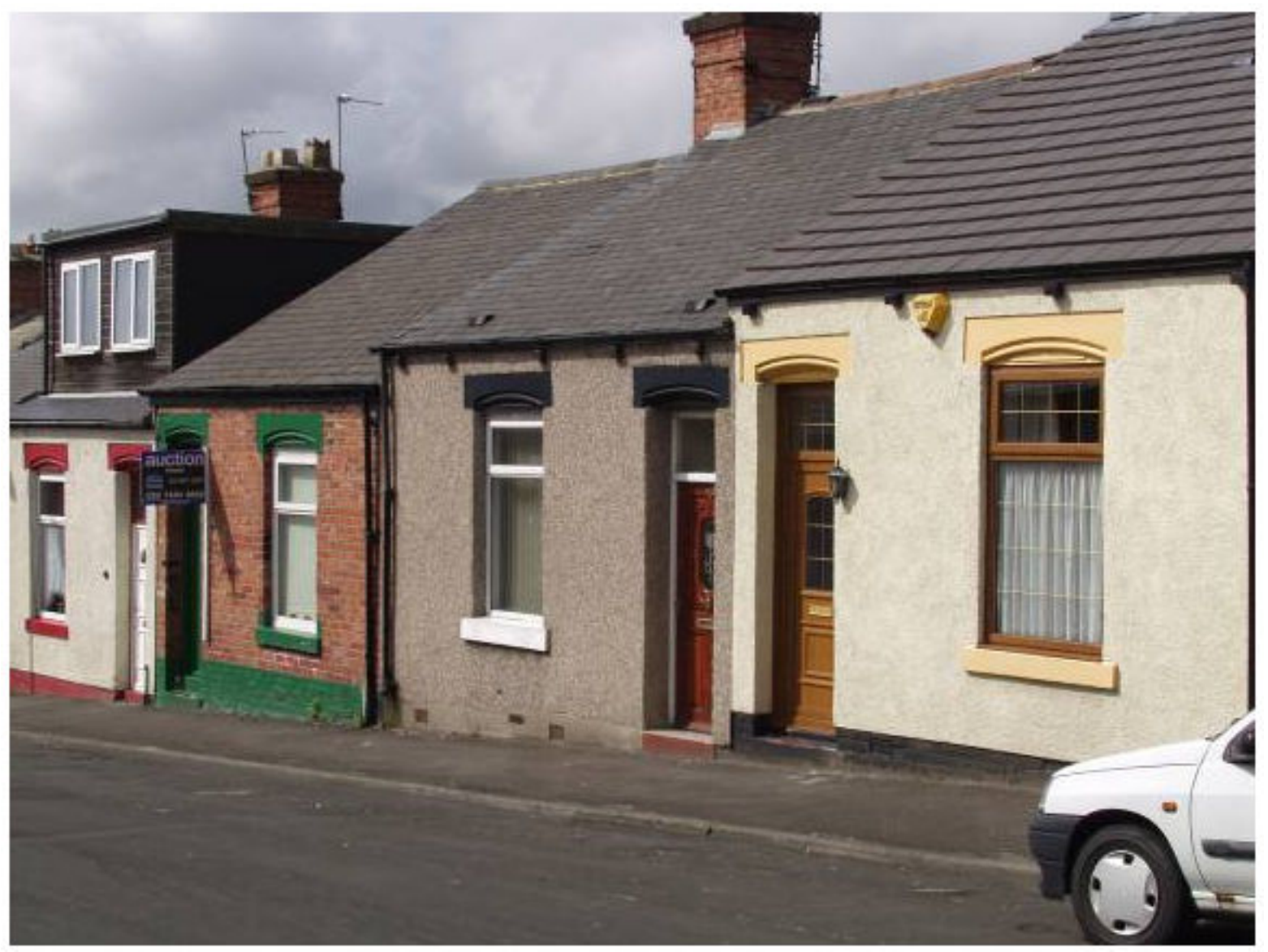

4.10 Because the basic house is so small the scope for enlargement, even when a dormer is built as in the bottom house here, is very restricted.

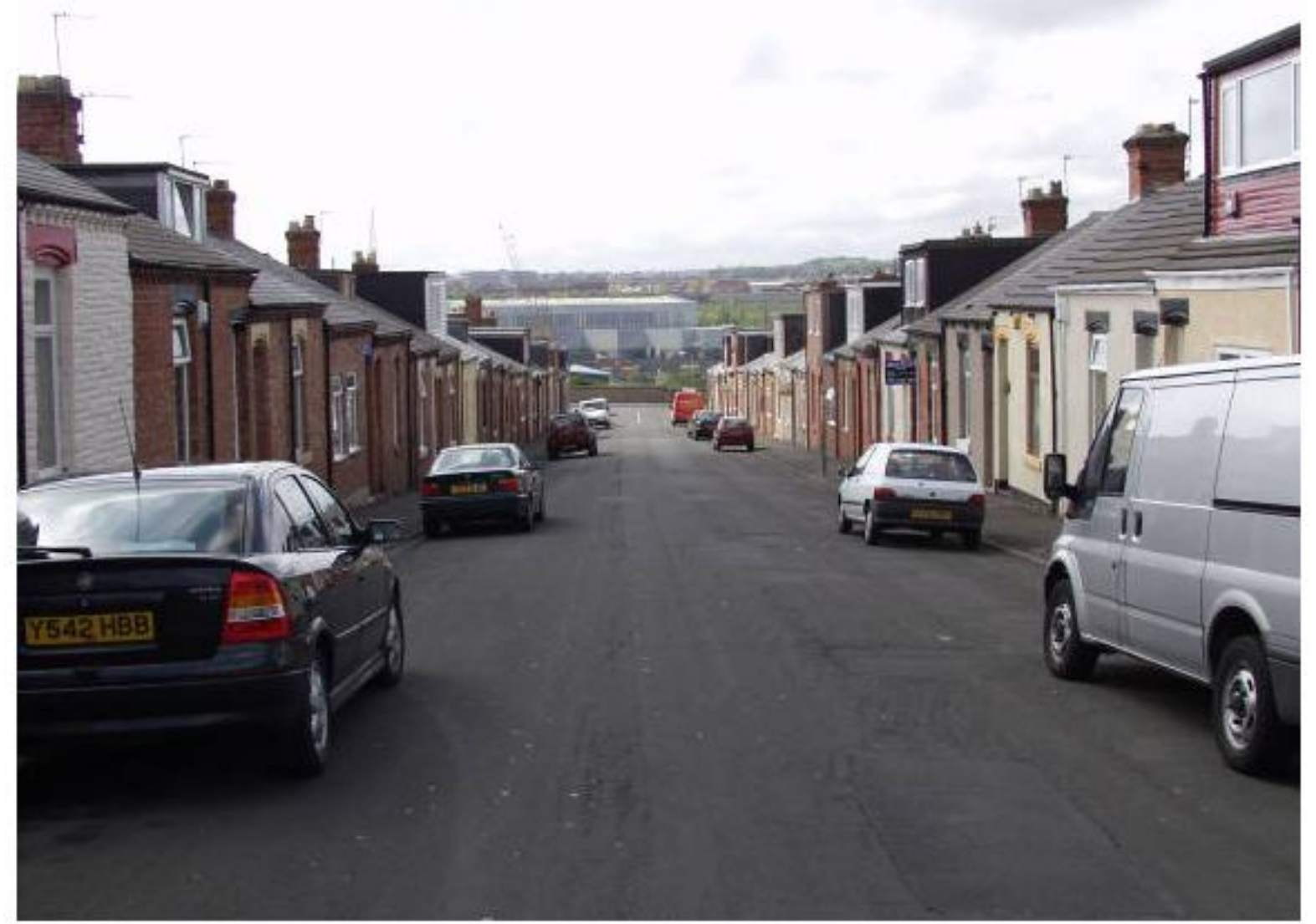

4.11 At the bottom of this picture we are looking across the river Wear to the sheds that were the former covered in berths of the Pallion yard, formerly Doxfords shipyard. 
4.12 The different shape, size and relation to the market of these physical occupational communities exercised an effect on the trajectory and sustainability of those communities once other types of housing became available. In the immediate post-war years Sunderland council embarked upon the biggest council housing program undertaken anywhere in England. One effect of this program was to reshape occupancy of the existing housing stock. As Norman Dennis (1970) has shown in his analysis of census data, in relation to population shifts between 1951-61 in Sunderland, some of the wards, especially those where shipbuilding employees predominated showed an interesting pattern.

Of particular importance is the outflow of population from the wards bordering the river, Monkwearmouth, Deptford, Bishopwearmouth, Roker and Pallion, in which were particular concentrations of shipyard workers. Added to this is the rise of structurally separate dwellings in all these areas. In other words there was an absolute outflow of population from these 'shipbuilding' wards accompanied by a relative dilution in the physical concentration of the population remaining in these areas. (Roberts, 1993, p81)

4.13 Of the wards bordering the river the one to show the smallest outflow during this period was 'Colliery', the area of mining housing next to Wearmouth pit. The existence of subsidized colliery housing of a decent size ensured that miners did not flock away to the new council estates on the periphery of the town in the way that shipbuilding workers did. So even in the context of a location within the town, mining communities exercised closure through tenure and preference in a way that shipbuilding communities did not. Similarly at Castletown further along the river, even when the new council house building occurred around the colliery housing and new estates were built abutting its boundaries, it was still referred to by those in the locality as 'the village'. The defence of the boundaries of the occupational community took place in terms of symbolic representation as well as the built environment. Insofar as the physical occupational community presents an opportunity for the retention of solidaristic relations outside of work as well as within, it would seem that even given an urban setting, miners had more potential than shipbuilding workers. The other side of this argument is of course to do with the workplace itself and the way in which that interacts with community.

\section{Work, solidarity and division.}

5.1 Whilst both mining and shipbuilding could be seen as examples of extreme occupations the nature of the labour process and the division of labour that related to the two industries were very different. Mining was seen at least in formal terms as a largely unskilled occupation. This was to bequeath a particular form not only to the community but also the form of trade union organisation. The importance of the perceived homogeneity of miners and their communities, however much the real situation may have varied, had implications for the type of trade unions and their mode of operation that was to develop. In many ways miners represented a particularly extreme form of an unskilled industry. Miners were the first and most thoroughly organized unskilled workers union and the contrast with their contemporary craft unions are worth noting,

No other unskilled group was able to organise so early and with such completeness as the miners did. However, where skilled groups built their organisations upon exclusion and the apprenticeship system, coal miners relied on political action to produce solidarity. (Beynon and Austrin 1994, p365)

5.2 The same authors go on to describe the way in which the interaction of the working conditions, forms of organisation and the nature of community effectively combined to produce forms of organisation and symbolic identification with occupation and identity.

In arduous and often brutal working and living conditions, the miners combined to form a stable union, supported it with regular subscriptions, and invested in banners which symbolised their involvement. The village as a 'community' became a vital aspect of their identities... (Beynon and Austrin 1994, p364)

5.3 We will return to the importance of the symbolism below. However, at this point it is perhaps worth noting that in his book 'Banner Bright: An Illustrated History of Trade Union Banners' John Gorman (1986) has assembled a record of this important form of representation. Mining banners dominate the account and the National Union of Mineworkers has fifteen separate page references in the index and forty five photos. Shipbuilding is not mentioned in the index, the boilermakers society is mentioned once, and a picture of one banner is shown and there is only one other picture of a banner that is connected with shipbuilding, which relates to 'The Friendly Sawyers, Whitehaven', importantly for the argument about the centrality of the product within shipbuilding the central picture of this banner is of a ship at sea.

5.4 One of the reasons for the lack of a consistent and coherent representation of the shipbuilding industry is that it was and is a composite industry. As a construction industry it draws on the labour of many crafts. As late as 1970 sociologists involved in the most important study of shipbuilding to be carried out up until that point commented that,

Despite very considerable changes which have taken place over the years a shipyard can still fairly be described as having a craft technology. (Brown and Brannen, 1970, p197)

5.5 The effect of the industry being an amalgamation of distinct trades meant that division rather than solidarity was often the dominating feature of the industry. As far as orientations to work are concerned shipbuilding workers have been described as displaying 'patterns of paradox' with elements of collective orientations and fragmentary orientations vying with each other (Cousins and Brown, 1972). Whilst the same authors identified a form of 'latent proletarianisation' this was dependent for its development on the 
breaking down of craft boundaries that was never realised on Wearside. What all this means is that in terms of identity shipbuilding workers often identified more with their specific trades than with the industry as a whole. There were multiple levels of fragmentation at work. Firstly, there was a difference between the metal trades such as boilermakers, platers and shipwrights and so on and the outfitting trades such as plumbers, joiners, carpenters electricians etc. The former saw themselves as being truly shipbuilding trades with little opportunity to ply their trades outside of the industry other than perhaps in structural steel work. The outfitting trades however had much in common with those in the building trade and the barriers between the two industries were often permeable. Also historically different payment systems had applied to the two groups. The metal trades had traditionally been paid on piece rates and the outfitting trades tended to be paid time rates. Again the importance of this was that forms of identity were claimed within the trade groups rather than as shipbuilding workers per se. Indeed insofar as those outside of the industry saw such workers as an homogenous group this could be taken as a slight! As a former industrial chaplain in the Wear yards observed,
....in Pallion, in the yards, you will find many a plater and shipwright and plumber, to mention only three of many shipyard trades, who are highly skilled men. They know they are skilled, and feel that the public is inclined to look down on these as mere shipyard workers. (Hopkins, 1954, p.110)

5.6 This identification with skilled trade rather than any overarching industrial identity was retained in the shipyards of Wearside up to the point of closure. This was in spite of formal moves to promote full interchangeability across trade groups forced through by management. However this was experienced by workers as both an assault and a shame. Insofar as it dismissed vertical demarcations skilled men thought it an affront to their status, as one painter declared,

\section{It's ridiculous. I've been working in the joiner's shop today, sweeping up - me, a skilled painter! (quoted in Roberts, 1993, p190)}

5.7 As management attempted to dissolve horizontal demarcations workers took the money for a scheme that offered little chance of resistance in the context in which management were also seeking to obtain enough 'voluntary' redundancies.

The retraining was seen as a mockery, but workers took the $£ 75$ given to those who volunteered. A shipwright explained, 'I served a five year apprenticeship to become a shipwright but now after three days hanging about with the welders I'm a welder, three days I'm a rigger, two days I'm a burner and two days and I'm a plater!' (Ibid)

5.8 The labour process in mining was one that emphasised industrial identity and this was reflected in the nature of the industrial trade unionism of the NUM. In shipbuilding the craft division of labour did not supply any coherent and overarching industrial identity and the form of labour organisation adopted reflected this. The dominance of craft trade unionism made it no coincidence that in the early post-war period the shipbuilding industry became almost synonymous with a type of industrial action where, rather than workers struggling against employers, they fought each other within demarcation disputes. However, structures do not mechanically determine historical process, although they do reflect a dialectic of the accretion of past action and may predispose actors to typical forms of future social action. In order to appreciate this we will now look at the way that industries met their demise.

\section{Heroic defeats and un-fought wars}

6.1 The miner's strike of 1984-85 was an unprecedented dispute. In spite of the government attempting to represent it as being about the closure of uneconomic pits, it was clear from the start that there was a far wider agenda being pursued. Thus, as early as 1982 when Norman Siddall took over as Chairman of the coal board, 'he came under relentless pressure from the government to prepare for an eventual showdown with the NUM' (Goodman, 1985, p33). Siddall himself was of the view that the industry could be stabilised without a confrontation. However, after the re-election of the Thatcher government in June 1983 a new chairman was appointed. Ian MacGregor was more in tune with Thatcher's belief that confrontation with the NUM was necessary in order to push forward the agenda of trade union reform. As Goodman observed the conflict was fuelled by,
...the determination of the Thatcher government to avenge the defeats inflicted on the Heath government in 1972 and especially in 1974; or the prime minister's own conviction that one day the miners had to be taken on and defeated if her own crusade against trade union 'monopoly power' was ever to succeed. (Goodman, 1985, p 14)

6.2 The full power of the state was arrayed against the miners and with careful planning of aspects of the confrontation from as early as 1982 then the odds were stacked against the miners. If the eventual outcome was defeat then it was indeed a heroic defeat which symbolised far more than a debate about the economic viability of deep coal mining.

The miners' strike of 1984-5 is a landmark in the political and economic development of postwar Britain. In the breadth of the issues involved, and in the drama of its action, it stands out .... as a major social and political event. In its compass it is quite staggering. Initiated by a threat to cut capacity and jobs in the coal industry it is the first major strike of any duration to be fought over the question of employment...In the sincerity of the people involved - women and men - as they talk about the threat to mining villages, to 'whole communities' and to the futures of their children, the strike evokes a deeply human response. (Beynon, 1985, p1) 
6.3 The scope of the dispute was indeed wide and as others have argued it had a significance that reached well beyond the communities that were directly involved. As Raphael Samuel put it,

In spite of the disappointments of the strike itself...the picture that comes from the villages in the year of the strike itself is one of hope, creativity and enjoyment. If communities of such vitality can be crushed, it is not only the inhabitants but the country as a whole that will be impoverished. (Samuel et al, 1986, p.39)

6.4 Moreover the significance of the dispute has been seen not in terms of an anachronistic backward looking defense of the indefensible; on the contrary, the significance has been seen by some to lie in its future relevance.

The miners' strike is being represented as the last kick of an old order. Properly understood, it is one of the first steps towards a new order. This is especially the case in the emphasis they have put on protecting their communities... what the miners, like most of us, mean by their communities is that the places where they have lived and want to go on living, where generations not only of economic but of social effort and human care have been invested, and which new generations will inherit. Without that kind of strong whole attachment, there can be no meaningful community. (Quoted in Richards, 1996, pp 230-31)

6.5 The Thatcher government may have won the initial battle itself but has by no means won the bigger historical war, where debate over interpretations of the strike and of the limitations of the market continue, in spite of the undoubted advance of the material impact and ideology of the market adopted now by 'New Labour' as well as the Tories. For the significance of the strike symbolized the importance of values beyond the narrowly economic and further encouraged the notion of miners and mining communities as the bearers of values opposed to the reduction of human relations to those based solely on the impersonal cash nexus. As such the symbolic appeal of mining and mining communities was shared by those beyond those communities themselves.

6.6 In the wake of the 'defeat' of the miners the Tory government turned their sights on other state run 'sunset' industries including British Shipbuilders. Again plans had been laid in the early 1980's for the rundown of the industry. In the end the final closure of the yards on Wearside was sealed as part of a deal between the Department of Trade and Industry and the European Commission which agreed the closure as a trade off for the over-subsidisation of the privatization deals of yards elsewhere. (Roberts, 1993, p216). The story of the run up to that closure is a tale of tragedy, where changes to the labour process were initiated with the overt intention of management to make production more efficient. In the context of the eventual reason for closure the explanation of the changes as being oriented towards producing enough voluntary redundancies looks a more compelling explanation. Resistance to the managerial onslaught was forthcoming at an individual level with examples of sabotage and at least one occasion of physical assault upon a senior manager. However, the basis for a collective stand in defense of the industry was felt to be lacking. Little leadership was shown by unions nationally as different areas were picked off one by one. Moreover an important context was the then recent defeat of the miners and a belief that you could not fight the state.

6.7 A collective stand was not taken then and throughout the 1980's rounds of 'voluntary' redundancies proved the only way out for workers that were finding the managerial assault upon working practices and thereby craft based identities intolerable. In 1981, in spite of union officialdom speaking of resistance that would be forthcoming more than 700 men 'volunteered' for redundancy even though unemployment in the town was running at over 17 percent. The regional organizer of the General and Municipal Workers Union resigned in disgust arguing that,

They are betraying their forefathers, throwing away - for short-sighted and selfish reasons job opportunities for the young and putting shackles on their trade union negotiators...I say the shipyard workers on the Tyne and Wear need a bit of fight in their bellies like the miners. Do they not realize we are a maritime nation and as such shipbuilding in this country could never be finished. (quoted in Spence 1987, p 97)

6.8 Throughout the 1980's the rounds of redundancy continued together with the ferocity of the managerial assault upon working practices the point at which to take a collective stand was never apparent. And the level of demoralization reached new heights. As one shipwright put it,

Every Monday morning you go in you might as well bend over - you're waiting to be

buggered!...I don't care what anyone says, there has not been one voluntary redundancy on

this river. Blokes have been hounded, abused and pushed into it. (quoted in Roberts, 1993, $p$ 185)

6.9 In this context workers reversed the connection between work and claims to dignity, as one plumber suggested.

It's become a matter of dignity - I got to get out. I wouldn't wish that set-up on my worst enemy let alone my son. He's better off without it. I've got my dignity and my redundancy! (quoted in Roberts, 1993, 186)

6.10 The lack of any collective stand meant that the shipyards of Wearside bled to death, albeit in the context where their ultimate demise had already been carefully planned. The effect of this in the shipbuilding communities of Wearside was to produce a situation in which everyone was blaming everyone else for the rundown of the industry. Workers were divided by generation with older workers blaming the 
younger and vice versa. The basis for any collective resistance was unclear as the industry itself was riddled with fault lines that ran through both work and community. At the point of closure in 1988 the contrast with the mining industry could not have been starker.

Ideologically the workers had nowhere to go. In their experience nationalisation had been the vehicle of their oppression. A feeling that you cannot fight the state, borne out by the result of the miners'strike, again fragmented the solidarity of the workforce and so reduced the potential for collective action. Yet the attacks by the representatives of labour on those selling their 'birthright' by taking their redundancy is misplaced. It has been the failure of the labour and trade union movement to take initiatives on behalf of the workforce during the years of strength which has resulted in such an easy victory for those currently running down the industry. Given this rundown, the changes in the organization of the division of labour confronted workers merely as an attempt at humiliation of the 'captives' before their final 'execution'. On the evidence available this seems in some respects not to be too far from the truth. (Roberts, 1993, p201.)

6.11 The public and collective struggle of miners and their communities taking a stand against the forces of a malicious state had an appeal that resonated well beyond those communities themselves. They may have been defeated but they can be proud of their stand. On the other hand the private battles of the workers in the yards go largely unrecorded. Lack of any collective stand is put down to cowardice and lack of 'fight in their bellies'. If mining was the industry that was murdered it appeared that as far as shipbuilding on Wearside was concerned it was a case of suicide. Clearly one might want to remember and identify with heroic defeat but a case of apparent desertion in the face of fire may be best forgotten! I have argued that it is in the interaction of these features of the two occupational communities together with the availability of iconic images that appeal beyond the communities themselves and the perceived willingness of those communities to stand for something that explains the rather different trajectories with respect to the visibility of collective memory.

\section{Discussion and conclusion.}

7.1 I started this paper by setting myself the task of addressing the question as to why in post-industrial society the collective representation of some industries and claims for memory seems easier to witness in relation to some forms of work rather than others. More specifically, with respect to Sunderland at one time 'the biggest shipbuilding town in the world' why is it that evidence of the past activity of coal mining is celebrated when shipbuilding seems to be far less apparent? In attempting to open up this discussion we have looked at the nature of the two industries themselves and the communities that surround them making a complex historical individual. Some attention was paid to the solidity and internal coherence of the physical occupational community and we looked at the way in which the two industries met their demise. Finally I have made some suggestions about the way in which some industries are represented (or not) through iconic images.

7.2 I have used images throughout this paper in a variety of ways. Firstly, as representing the objects of collective representation, the sculptures themselves, I have sought to graphically represent the visual forms taken. Whilst a picture may not always represent a thousand words the visual appearance of forms can deliver an appreciation of forms that would otherwise be difficult to convey in words alone. Similarly, in including aspects of wider context, such as the lamp in front of the 'aged miners cottages' or the lamp at the Stadium of Light a photograph can convey the importance of location as part of a complex narrative. In deploying the photographs of the different types of housing my primary goal was to give a graphic representation of the differences of scale involved between the different types of housing (the inclusion of parked cars perhaps helped to give a benchmark here) as part of the discussion about the creation, including the role of the market and the subsequent trajectories of physical occupational communities. The use of the secondary images representing workers from the two industries represents a rather different use of images. Such a strategy is one way of looking at, at least within one medium, of the general resources available for the representation of particular types of labour. It has the virtue of being an accessible way of gauging the homogeneity/heterogeneity of representations and of whether particular representations can be argued to stand for iconic images. The use of images and the importance of the visual for this paper is great. However, I would resist any move to downplay the importance of other aspects of the argument. The point I think is to use the visual to build upon and compliment the conceptual tools available within sociology more broadly, I would resist the temptation to fragment the use of imagery into a sub-specialism of visual sociology.

7.3 This is why I wish to suggest in this paper that how any empirical case comes together in realizing collective representations will be an outcome of the interaction of the visual, the cultural and the material. In particular the strength of support for the preservation of collective representations will depend not only on the strength of that commitment by the community itself but also on having a wider appeal beyond the bounds of that actual community. This is what the celebration of mining has been able to achieve. The heroic nature of the work in confrontation with elemental forces, earth, water, air and fire is something that occupations dealing with such forces share to a degree. For example fishing has been described in the following terms,

The image of the fishermen conjures up deep feelings: Biblical resonances of Galilee, echoes of childhood hymns, nostalgia for the last true hunters plying a trade that goes back to the very origins of humanity. The mind's eye fastens on the life ebbing from hundreds of tiny harbours and creeks around our coasts. We think of heroism in the face of winter danger, of the sea itself, and the struggle of mankind with the elements. (Thompson, Wailey and Lummis, 1983, p3) 
7.4 Mining shares with fishing a struggle with elemental forces. It also shares a feature of physically going beyond the boundary of everyday life to carry out an activity that is opaque to the everyday gaze, whether carried out several miles from land or beneath the surface of the earth. It also shares a quality of the mundane nature of its product, whether it be cod or coal, the real business is the extraction in an environment that few have or would want to experience. The labour is not upstaged by the product. Mining outdoes the fishing industry at least in popular memory in relation to the social heroism of the production of community and struggle with the coal owners, who owned the land and the housing and at times were of great influence in the nation state itself. A state that at times has cast miners in the role of a threat to democracy' as in the 1926 Strike or as Thatcher herself put it the 'enemy within'. Such labels themselves ensured that the struggles of the miners would assume a greater significance than that of a trade dispute, miners and mining communities have been politicised as much from the outside as from within. Miners and their communities have been ascribed with the message of being a bearer of oppositional values, sometimes expressed in politics with a capital $P$ and sometimes carried more broadly in the suffering of their communities in the face of aggression from the state. All of this has ensured that in the process of making claims to memory that project has been carried proudly from within and eagerly accepted for its symbolic value from without, even some businesses buying in to the mining spirit. Cross class and cross community sympathies ensure that the desire to preserve the heritage of the mining industry continues. The multiple combination of the structural features of mining work and communities allied to the heroic qualities ascribed to both were cemented in the public imagination through the titanic struggles of 84 and 85 . The industry may have been done to death but the community remains undefeated. In Sunderland this was allied with forms of occupational community that drew not only from the immediate locales but also from 'pit villages' to the West of the city which had witnessed their smaller mines closed down in earlier rounds of closure. The traditional moderation of the Durham coalfield was negated by this being clearly a last stand.

7.5 The contrasts with shipbuilding are clear. The work itself may be complex but it does not work primarily with elemental forces, at the end of the day it remains a construction industry. The very complexity of its division of labour ensured that the effect of closure of the industry would be felt unevenly by its workers, some of whom had a market for their skills elsewhere beyond the shipyard. In the popular imagination and beyond its immediate communities (clearly it isn't as geographically widespread as mining) there is sometimes confusion about what is involved, people often confuse shipyards with dock work. The most impressive visual thing to come out of a shipyard are the ships themselves that sail away, often to exotic lands, providing an added dimension to the machine aesthetic. Added to all of this in the case of Wearside there was no line drawn in the sand, no point at which to defend the industry and the wider community. Rather, faced with daily assaults upon their dignity that went on almost for a decade, the preservation of dignity was aligned with getting out and away. The salt in the wounds being that those who didn't have to endure the same, branded those who did as 'selfish' and 'short-sighted'. Such accusations tend to stick, moreover they are corrosive to any sense of well-being and self-worth related with identity to work. Is it any wonder that in such a context many ex-shipyard workers wanted nothing other than to forget the past and put that pain behind them?

7.6 The passing of mining and shipbuilding in Sunderland need to be understood in different frames. If the one can be seen as murder the other is, at least as seen by some, a case of suicide. The contemplation of these two acts is different and perhaps usefully understood within the framework developed by Freud in making the distinction between mourning and melancholia.
Mourning is connected to the loss of a loved one or the loss of some abstraction, such as a homeland, liberty or an ideal. Mourning passes with the elapsing of time needed for the "work of grief." In mourning "deference to reality gains the day," even if its "behest cannot be at once obeyed." In melancholia the loss is not clearly defined and is more unconscious. Melancholia doesn't pass with the labour for grief and has less connection to the outside world. It can lead to self-knowledge or to continuous narcissistic self-flagellation. "The complex of melancholia behaves like an open wound, draining the ego until it is utterly depleted." (Bogin, 2001, p.55)

7.7 The mourning for the mining industry has been shared by the outside world and this sharing will ensure that there is recognition of ,
...the construction of specific 'memoryscapes', which materialize memory by assembling iconographic forms and producing stages for organizing a relationship with the past. (Edensor 2005130)

7.8 Its symbolism is understood and significance as the bearer of meaning beyond the market has wide appeal. In this it perhaps stands as a case of 'reflective nostalgia'. This is defined by Bogin as 'a form of deep mourning that performs a labour of grief both through pondering pain and through play that points to the future'(ibid). As such the enthusiasm for a memorialisation of mining is not backward looking but is a form of nostalgia that preserves the past ideal and keeps it alive as a source of hope for the future. In the case of shipbuilding it would seem that nostophobia remains the dominant frame, especially for some of the ex-workers themselves. I suspect that it would be wrong to draw overly optimistic conclusions about the future potential for the development of a collective memorialisation of shipbuilding in Sunderland. If there is such potential it may have to wait for later generations, and if such generations decide to unearth this particular past then I suspect that it may be memories of products rather than processes that emerge, stories of objectified labour rather than real living labour, commodity fetishism projected historically. The irony will be that alienated memory may be all that remains of labour processes that in their craft conception were the opposite of alienated labour.

\subsection{In speaking of collective representations of post industrial places then we need to remember that the}


devil is often in the detail. Places that seem to share an industrial past are often stratified by meanings that can indicate opposing conclusions. We need to face these complexities if we are to produce a more comprehensive understanding of the meanings of deindustrialisation. The importance of understanding such processes as complex historical individuals is paramount. The resources for iconic representation have both general and more specific features but their potential for realization is never simply a reflex of a single reified structural context. The interaction of agency and structure is realized through the coming together of a myriad of levels and elective affinities. Present social action continues to produce and reproduce our images of the past utilizing and creating resources in accordance with objective possibilities and (inter)subjective preoccupations.

\section{Notes}

${ }^{1}$ The initial title for this article included the term 'collective memory'. After further research and reflection I now see this term as problematic, for as Alessandro Portelli has suggested,

If all memory were collective, one witness could serve for an entire culture - but we know that this is not so. Each individual, especially in modern times and societies, derives memories from a variety of groups, and organizes them in an idiosyncratic fashion. Like all human activities, memory is social and may be shared; however, like langue as opposed to parole, it only materializes in individual recollections and speech acts. It becomes collective memory only when it is abstracted and detached from the individual: in myth and folklore, in delegation in institutions - that organize memories and rituals in a whole other than the sum of its separate parts.' $(1997,157)$

Given this 'collective representations and divided memories' seems to capture my initial intent in this paper.

\section{References}

BEYNON, H. (1985) Digging Deeper: Issues in the Miners Strike, London, Verso

BEYNON, H. and Austrin, T (1994) Masters and Servants; Class and Patronage in the Making of a Labour Organisation, London, Rivers Oram Press

BOGIN, S. (2001) The Future of Nostalgia, New York, Basic Books

BROWN, R.K. and Brannen, P. (1970) 'Social relations and social perspectives amongst shipbuilding workers - a preliminary statement' in Sociology, Vol 4.

BYRNE, D. (2001) Understanding the Urban, Basingstoke, Palgrave

BYRNE, D and Doyle, A. (2004) 'The Visual and the Verbal: The Interaction of Images and Discussion in Exploring Cultural Image', in Knowles, C. and P. Sweetman (eds) Picturing the Social Landscape: Visual Methods and the Sociological Imaginations, London, Routledge.

CHRISMAS, L. (1998) Coaldust Grins: Portraits of Canadian Coal Miners, Calgary, Cambria Publishing

COUSINS, J. and Brown, R.K. (1972) Patterns of paradox: shipbuilding workers' images of society,

Durham University Department of Sociology and Social Administration, Working Paper in Sociology, No 4.

CHURCH, R.A. and Outram, Q. (1998) Strikes and Solidarity: Coalfield Conflict in Britain 1889 - 1966, Cambridge, Cambridge University Press.

COWIE, J. and Heathcott, J. (2003) Beyond the Ruins: The Meanings of Deindustrialization, Ithica, Cornell University Press

DELANY, P. (2004) Bill Brandt: A Life, London, Jonathan Cape

DENNIS, N. (1970) People and Planning, London, Faber and Faber.

DOUGAN, D. (1968) The History of North East Shipbuilding,London, Allen and Unwin.

EDENSOR, T. (2005) Industrial Ruins: Space, Aesthetics and Materiality, Oxford, Berg

GALLACHER, W. (1978) Revolt on the Clyde,London, Lawrence and Wishart.

GOODMAN, G. (1985) The Miners Strike, London, Pluto

GORMAN, J. (1986) Banner Bright: An Illustrated History of Trade Union Banners, Buckhurst Hill, Scorpion Publishing Ltd

HINTON, J. (1973) The First Shop Stewards Movement, London, Allen and Unwin.

HOPKINS, C. (1954) Pallion 1874 to 1954: Church and People in a Shipyard Parish, Sunderland, Wearside 
Printing Company Ltd.

KERR, C. and Siegal, A. J. (1954) The inter-industry propensity to strike'. In Kornhauser et al. (eds) Industrial Conflict, New York, McGraw-Hill

LINKON, S.L. and Russo, J. (2002) Steel-Town USA: Work and Memory in Youngstown, Kansas, University press of Kansas

LUCIC, K. (1991) Charles Sheeler and the Cult of the Machine, London, Reaktion Books

RICHARDS, A. J. (1996) Miners on Strike: Class solidarity and division in Britain, Oxford, Berg

ROBERTON, C. (2004) Wearside at Work in the $20^{\text {th }}$ Century, Sunderland, TUPS Books

ROBERTS, I. (1993) Craft, Class and Control: The Sociology of a Shipbuilding Community, Edinburgh, Edinburgh University Press

ROBSON, B. (1971) Urban Analysis, Cambridge: Cambridge University Press.

SAMUEL, R, Bloomfield, B and Boanas, G. (1986) The Enemy Within: Pit Villages and the Miner's Strike of $1984-5$, London, Routledge and Kegan Paul.

SMITH, J.W. and Holden, T.S. (1947) Where Ships are Born: Sunderland 1346 - 1946, Sunderland, Thomas Reed and Co.

SPENCE, J. (1987) 'Industrial Relations in Wearside Shipbuilding 1965 - 1981' in A. Potts (ed) Shipbuilders and Engineers, Shipbuilders and Engineers, Newcastle, North East Labour History Society.

STEPHENSON, C. and Wray, D. (2005) 'Emotional Regeneration through Community Action in Post Industrial Mining Communities: The New Herrington Miner's Banner Partnership', in Capital and Class, , 2005

THOMPSON, P., Wailey, T. and Lummis, T. (1983) Living the Fishing, London, Routledge and Kegan Paul VILANDER, B. (1999) Hoover Dam: The Photographs of Ben Glaha, Tucson, The University of Arizona Press

WEBER, M. (1949) The Methodology of the Social Sciences, New York, The Free Press 